\title{
Co-existence of organic matter and live plant macrophytes under flooded soil conditions acidify sulfidic soil of acid sulfate soils
}

\author{
Patrick S. Michael ${ }^{1,2}$ \\ ${ }^{1}$ School of Biological Sciences, The University of Adelaide, Adelaide, SA 5005, Australia \\ ${ }^{2}$ Department of Agriculture, PNG University of Technology, Lae, MP 411, Papua New Guinea \\ Corresponding Author: patrick.michael@pnguot.ac.pg \\ [Accepted: 08 February 2020]

\begin{abstract}
Acid sulfate soils (ASS) are formed under waterlogged or reducing soil conditions. These soils either contain sulfuric acid or have the potential to form it, in an amount that can have detrimental impacts on the environment. Under undisturbed soil conditions, the sulfidic soils are benign unless exposed to atmospheric oxygen which leads to oxidation and production of sulfuric acidity. In this study, the changes in $\mathrm{pH}$, redox and sulfate content of sulfidic soil following addition of organic matter, establishment of plant macrophytes or turnover of organic matter from the plant macrophytes co-existing under flooded conditions was investigated. The results showed in the absence of plant macrophytes, organic matter addition induced ameliorative effects, whereas presence of plants macrophytes led to acidification. The reduction reactions of the added organic matter and the anoxia created by flooding were ineffective in reducing the amount of oxygen that was pumped into the rhizophore via the arenchymatous tissues. Under falling soil moisture regimes, e.g. during a drought event as a result of changes in climatic conditions, the presence of this type of plant species would aerate the reduced soil conditions. Aeration will then lead to oxidation of sulfides, producing sulfuric acid $\left(\mathrm{H}_{2} \mathrm{SO}_{4}\right)$, which in turn will have negative impacts when released into the environment.
\end{abstract}

Keywords: Sulfidic soil - Organic matter - Live plants - pH - Eh - Sulfate content.

[Cite as: Michael PS (2020) Co-existence of organic matter and live plant macrophytes under flooded soil conditions acidify sulfidic soil of acid sulfate soils. Tropical Plant Research 7(1): 20-29]

\section{INTRODUCTION}

Under general soil use and management conditions, oxygen demand of plant roots is met by those that reach the rhizosphere via channels created by the roots (Michael 2018a). In flooded soils of reduced conditions, adapted plants use specialized structures to transport oxygen from the shoots to support root respiration (Marks et al. 1994, Armstrong et al. 1996, Simpson et al. 2010, Michael 2019). The oxygen in the rhizosphere offers various advantages in almost all soil types except acid sulfate soils (ASS). In ASS, oxygenation would lead to oxidation of sulfides (Buschmann et al. 2008, Baldwin et al. 2009), which in turn would generate sulfuric acidity (Pons 1973). Under natural soil conditions, plant turnover adds decaying organic matter so that both live and dead plant material co-exist (Michael \& Reid 2018), influence microbial activity in the rhizosphere and alter the chemistry (Michael 2018b).

The effects of oxygen delivered into the rhizosphere and the organic matter shed from mature stand of plants co-existing on sulfidic soil is not yet well investigated or limited to a few studies (Yan et al. 1996, Shamshuddin et al. 2004). We have reported in a number of studies that organic matter of dead plant matter addition ameliorates ASS either under aerobic or anaerobic soil conditions (Michael 2015a, Michael et al. 2015, 2016). In our other related studies in ASS, in almost all cases live plant macrophytes existing alone acidify the soil, even under flooded conditions (Michael et al. 2017, Michael 2018c). Recently, we reported that live Phragmites australis (Cav.) Trin. ex Steud. (Common Reed) plants (a common wetland plant macrophyte) and added organic matter of dead plant matter co-existing acidify sulfidic soil even under flooded soil conditions (Michael \& Reid 2018).

The study of Michael \& Reid (2018) was extended by investigating the effects of live Typha angustifolia L. 
(narrowleaf cattail, another common wetland plant macrophyte) and added organic matter of dead plant coexisting on sulfidic soil $\mathrm{pH}$, Eh and sulfate content under flooded soil conditions. In addition, the belowground biomass (root) was quantified to assess the relationship between the changes in soil chemistry and the distribution of the biomass.

\section{MATERIALS AND METHOD}

Soil

The sulfidic soil was collected from Finniss River in South Australia at Wally's Landing (35 24028.28"S; $138^{\circ} 49054.37^{\prime \prime E}$ ). Details on soil classification using the Australian ASS Identification key (Fitzpatrick et al. 2008) and Soil Taxonomy (Soil Survey Staff 2014) are given in Michael et al. (2016). In addition, comprehensive lists of references containing further information on the soil morphology and geochemistry prior to rewetting (i.e. sites AA26.3 and FIN26) in Fitzpatrick et al. (2009) and after reflooding are given in table 1 of Michael et al. (2015, 2016, 2017). The 'sulfidic material' (Soil Survey Staff 2014) used in this study is representative of typical global inland and coastal wetlands, in terms of sulfidic and organic matter content.

The $\mathrm{pH}$ of the fresh sulfidic soil material was 6.7 when measured in water $\left(1: 5 \mathrm{w} / \mathrm{v} ; \mathrm{pH}_{\mathrm{w}}\right)$. The water holding capacity based on wet and dry weight was estimated to be $49 \%$. The estimation was made by setting soil samples at $100 \%$ field capacity after soaking in water and draining through a filter overnight. These soils were weighed to obtain the wet weight, and oven dried for 3 hours, then microwaved for 30 seconds to ensure removal of any residual moisture and reweighed to obtain a final dry weight. The residual organic matter content, estimated using the weight loss-on-ignition method (Schulte \& Hopkins 1996), was 10.6\%. The presence of sulfidic materials (minerals) capable of producing sulfuric acidity was measured by treating $1 \mathrm{~g}$ of sulfidic soil with $5 \mathrm{ml}$ of peroxide $(1: 5 \mathrm{w} / \mathrm{w})$ as per Ahern et al. (2004). The $\mathrm{pH}$ following peroxide treatment (pHox) was 1.4, a strong indication of the presence of a high amount of oxidisable sulfides.

\section{Organic matter}

To use as organic matter, the first three younger and fully open leaves of Phragmites australis were collected and prepared as previously described in various studies (Michael et al. 2015, 2016). All the leaves were chopped into pieces, air-dried overnight under room temperature and then oven-dried at $60^{\circ} \mathrm{C}$ for three days. The dry pieces were finely chopped using an electric blender to pass through a $\approx 0.5 \mathrm{~mm}$ sieve. The nitrogen content, analysed by ICP-OES using $0.5 \mathrm{~g}$ samples $(n=3)$ as described by Michael et al. (2015) was estimated to be $3.7 \%$. The carbon content was estimated to be similar to grass (leaf) clippings as per Rynk et al. (1992).

\section{Plant establishment}

The plants were established as described by Michael (2015). The Thypa plants were initially raised as shoots (plantlets) by rooting rock stocks in a rooting medium (compost: sandy loam 2:1 w/w). The well-rooted plantlets used in setting the experiments were approximately 8-12 weeks old. In each treatment, two plantlets each was transplanted which produced multiple shoots throughout the experiment. A dibble was used to make small holes, shoots or seedlings transplanted and the soil gently pressed to ensure the roots were in contact with the soil as would have been the case under any soil use condition (Michael et al. 2017, Michael \& Reid 2018). In all the experiments, the control treatments were not planted.

\section{Experiments and treatments}

The experiments described below were conducted in $50 \mathrm{~cm}$ tall $(9 \mathrm{~cm}$ in diameter $)$ stormwater tubes whose bottom ends were tightly capped (Michael \& Reid 2018). In all the tubes, the bottom $22 \mathrm{~cm}$ was filled with sand and the top $22 \mathrm{~cm}$ with $1300 \mathrm{~g}$ of sulfidic soil by weighing to add the exact amount in each tube. The treatments were replicated four times and set out in a complete randomized design under glasshouse conditions in polythene crates. In all the treatments, measurements were made from only three replicates from the top $22 \mathrm{~cm}$ of the sulfidic soil. The anaerobic treatments were always under flooded conditions with adequate amount of water ponding on the surfaces by regular addition of water (once in the morning and in the evening) (Michael et al. 2016).

\section{Root biomass quantification}

The root biomass was quantified as described by Michael et al. (2017) from the soil profiles from which the changes in $\mathrm{Eh}, \mathrm{pH}$ and sulfate content were measured. Soil from these sections was placed in a sieve $(0.05 \mathrm{~mm})$ and held under a gentle running tap water and the soil carefully broken up to free the roots using the aid of forceps. The loose soil particles were allowed to drain through but roots that were trapped by the sieve and those that floated during washing were collected. These roots were taken, gently washed again to remove soil 
material, placed in weighing boats and oven-dried for two days. The dry weights were taken by weighing, and weights of the replicates were pooled, averaged and kept as the final biomass data.

\section{Measurements}

Changes in redox potential (redox/Eh), $\mathrm{pH}$ and sulfate content were measured from the surface (0-20 mm), middle (50-100 mm) and deep (150-200 mm) soil profiles as previously described (Michael et al. 2015, 2016, 2017, Michael \& Reid 2018). Redox was measured using a single $\mathrm{Ag} / \mathrm{AgCl}$ reference and platinum (Pt) electrode combination using an automated data logger (Michael et al. 2012). To measure the Eh, a handheld electric drill, with a drill bit head the size of the Pt electrode, was used to make holes through the tubes with care taken to avoid disturbing the soil. The Pt electrode was inserted in the holes and the reference electrode inserted into the soil from the surface. This was allowed to equilibrate for 10 minutes and then Eh measured at 1 minute intervals for the next 10 minutes and averaged (Rabenhorst et al. 2009). These values were corrected for the reference offset to be relative to the potential of a standard hydrogen electrode by adding $200 \mathrm{mV}$ (Fiedler et al. 2007). The stability and accuracy of the electrodes were maintained according to Fiedler et al. (2007). The pH measurement in water $\left(1: 5 \mathrm{w} / \mathrm{v} \mathrm{pH}_{\mathrm{w}}\right)$ was undertaken as described by Michael et al. $(2012,2015)$.

Sulfate was extracted according to the method of Hoeft et al. (1973) for soluble soil sulfate. Replicate samples $\left(0.5 \mathrm{~g}\right.$ each) were placed in tubes with $1.5 \mathrm{ml}$ of an extraction solution $\left(0.2 \mathrm{~g} \mathrm{CaH}_{2} \mathrm{PO}_{4}, 12 \mathrm{~g}\right.$ glacial acidic acid and $88.5 \mathrm{~g}$ deionized water). After 30 minutes, soil was sedimented by centrifugation for 5 minutes, and duplicate aliquots from the three replicates were transferred into $4 \mathrm{ml}$ cuvettes and diluted with $1.5 \mathrm{ml}$ of the extraction solution. The samples were mixed with $0.7 \mathrm{ml}$ of $0.5 \mathrm{M} \mathrm{HCl}$, and $0.7 \mathrm{ml}$ of $0.1 \mathrm{M}$ barium chloridepolyethylene glycol reagent was added and mixed again. After 10 minutes, the samples were mixed again and the absorbance read at $600 \mathrm{~nm}$ using a spectrophotometer. The readings were compared with a standard solution of $0-2 \mathrm{mM} \mathrm{Na}_{2} \mathrm{SO}_{4}$. The initial sulfate content of the sulfidic soil ranged between $12-16 \mu \mathrm{lmol} \mathrm{g}^{-1}$ soil. The detection limit based on an absorbance reading of 0.1 of this method is $0.6 \mu \mathrm{lmol} \mathrm{g}^{-1}$ soil.

\section{Statistical analyses}

The Eh values obtained over a 10 minutes period, the $\mathrm{pH}$ and sulfate content were averaged and a treatment average obtained by taking the mean of the three replicates (Michael et al. 2012, 2014). To compare the treatment means, significant differences $(\mathrm{p}<0.05)$ between treatment means of each profile were determined by two-way ANOVA using statistical software JMPIN, AS Institute Inc., SAS Campus Drive, Cary, NC, USA. If an interaction between the treatments and profile depths was found, one-way ANOVA with all combination was performed using Tukey's HSD (honest significant difference) and pairwise comparisons.

Experiment 1: This experiment was conducted with Thypa plants established with organic matter incorporated in the soil (80:1, soil: organic matter $w / w)$ by bulk mixing and maintained under anaerobic (flooded) soil conditions. Bulk mixing was done by weighing out the amount of soil or organic matter needed using a portable scale at 80:1 (w/w), and thoroughly mixed in 201 mixing troughs using a spade. Only the treatment soils were planted and the control treatment soils set without plants.

Experiment 2: In this experiment, Thypa plants were planted in the sulfidic soil under anaerobic (flooded) soil conditions but without added organic matter to compare the results of experiment 1 . The control treatment soils were not planted.

\section{RESULTS}

\section{Combined effects of organic matter and live plants on $\mathrm{pH}$}

The principal aim of the experiments was to assess the roles of live plants and organic matter co-existing on sulfidic soil chemistry ( $\mathrm{pH}$, Eh and sulfate content) under flooded soil conditions. The expectation was that under reduced soil conditions as a result of flooding, the sulfidic soil would remain reduced $(\mathrm{pH}>4)$. However, in the planted soils, the arenchymatous would pump oxygen into the rhizosphere, resulting in oxidation of the oxidisable sulfides, lowering the soil $\mathrm{pH}(<4)$, oxidising the soil and increasing the sulfate content. The second aim was to assess the distribution of the root biomass and whether organic matter addition had influenced the biomass distribution. Under the flooded soil conditions, root biomass was bigger and equally distributed at the lower profiles expect in the surface soils following organic matter addition in the sulfidic soil (Fig. 1). In the planted soil where organic matter and live roots co-existed, the $\mathrm{pH}$ was lowered (the soil has acidified) to near 6 units from an initial $\mathrm{pH}$ of 6.7. In the absence of plants, organic matter addition increased the $\mathrm{pH}$ to near 7 at the surface and remained unchanged at the deep soils. No clear relationship between the biomass distribution and changes in soil $\mathrm{pH}$ was evident. 


\section{Combined effects of organic matter and live plants on redox potential}

As with $\mathrm{pH}$, biomass distribution had no clear relationship with redox (Fig. 2). In the surface (0-20 mm) of the planted soil, Eh was reduced to $200 \mathrm{mV}$ and deep reduced to near 11 and $10 \mathrm{mV}$ (Fig. 3), respectively. In the control soil, Eh was reduced to moderately reduce from surface to deep soil, ranged from $-20 \mathrm{mV}$ within the surface to $-110 \mathrm{mV}$ at deep, respectively. These results show plants oxidised the soil despite the anoxia created by flooding compared to the unplanted soil which remained reduced at deep as expected.

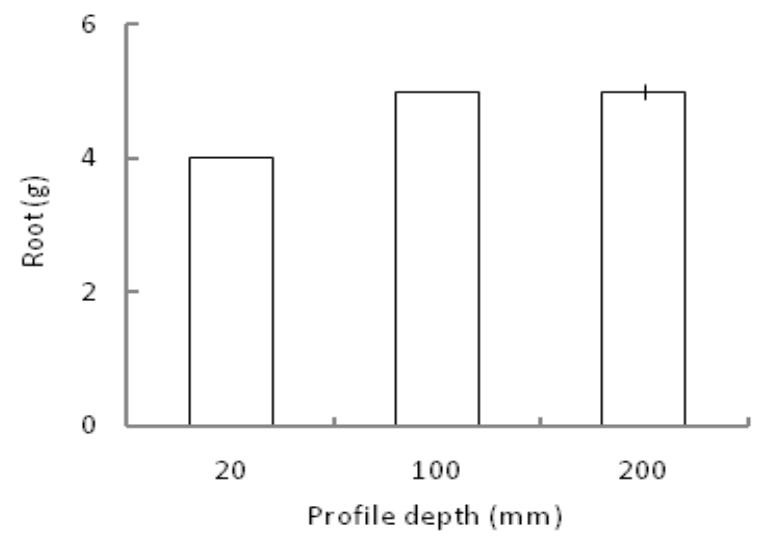

Figure 1. Distribution of root biomass with organic matter under flooded soil conditions after 6 months. [The values are mean \pm s.e. of three replicate measurements]

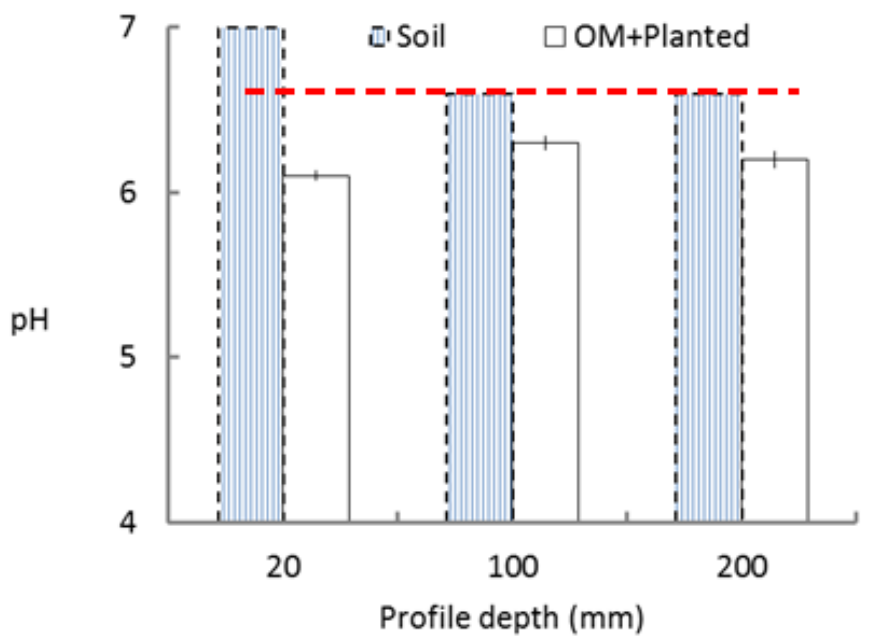

Figure 2. Effects of organic matter with or without live roots on $\mathrm{pH}$ under flooded soil conditions after 6 months. The values are mean \pm s.e. of three replicate measurements. The dotted line is the initial $\mathrm{pH}$. An asterisk indicates significant difference $(\mathrm{p}<0.05)$ between treatment and control at same depth.

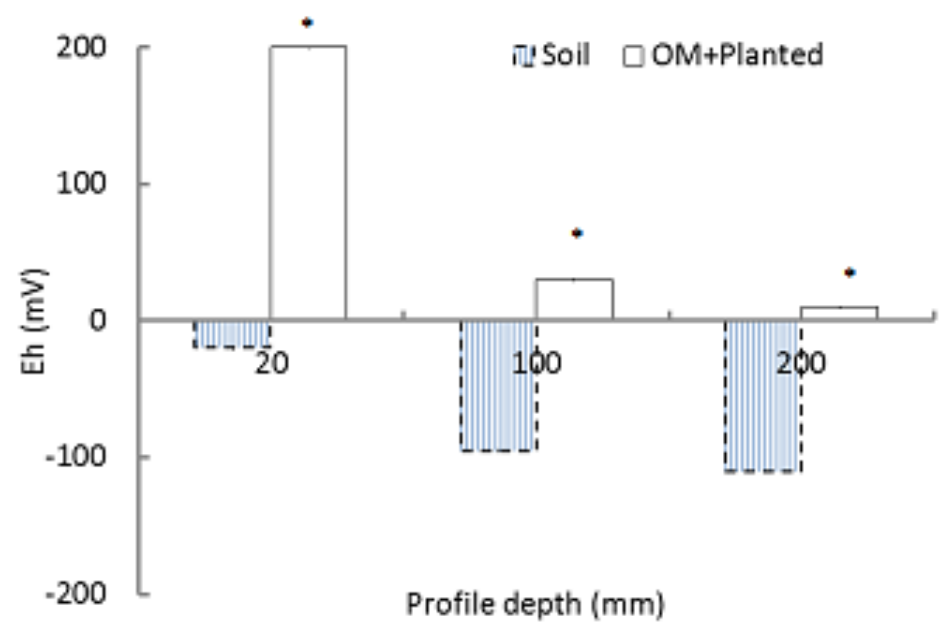

Figure 3. Effects of organic matter with or without live roots on redox potential under flooded conditions after 6 months. [The values are mean \pm s.e. of three replicate measurements. An asterisk indicates significant difference $(p<0.05)$ between treatment and control at same depth] 


\section{Combined effects of organic matter and plants on sulfate content}

In the organic matter amended soils without live roots, the sulfate content was near $3 \mu \mathrm{mol} \mathrm{g}^{-1}$ soil (Fig. 4). In the amended soil with organic matter co-existing with live roots, the sulfate content was smaller within the surface and higher at deep soils, ranging from 6 to $14 \mu \mathrm{mol} \mathrm{g} \mathrm{g}^{-1}$ soil. As in $\mathrm{pH}$ and Eh, no clear relationship between biomass and sulfate content was observed. There is strong evidence that in the presence of plants, microbial reduction of sulfate did not really take place, even when organic matter was available as a metabolic substrate.

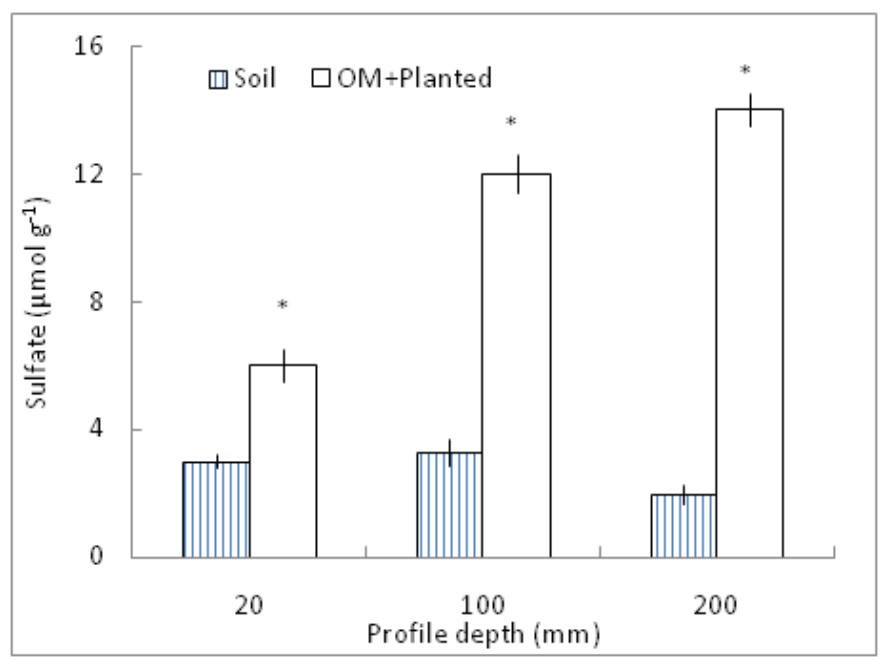

Figure 4. Effects of organic matter with or without live roots on sulfate content under flooded soil conditions after 6 months. [The initial sulfate content range from $12-16 \mu \mathrm{mol} \mathrm{g}$. The values are mean \pm s.e. of three replicate measurements. An asterisk indicates significant difference $(\mathrm{p}<0.05)$ between treatment and control at same depth]

\section{Effects of live plant alone on soil $\mathrm{pH}$}

In the absence of organic matter amendment, the root biomass was high at the middle than at the surface or deep soils (Fig. 5). In the unplanted soil, the $\mathrm{pH}$ remained nearly unchanged with a small decrease within the surface soil. In the planted soil, the $\mathrm{pH}$ decreased to near 5, with a substantial decrease to near 3 units at deep soil. As seen in the previous experiment, there was no clear relationship between the biomass distribution and the changes in soil pH that were measured (Fig. 6). The overall change in $\mathrm{pH}$ resulted in 1.5 units at the surface to 3.1 units at deep soil, respectively. This is a strong indication that severe acidification occurred at the deep soil.

\section{Effects of live plants alone on redox potential}

Under the flooded soils, the redox of the planted soil was highly oxidised within the surface to oxidise at deep, Eh ranging from $290 \mathrm{mV}$ to $90 \mathrm{mV}$ (Fig. 7). The influence of biomass on the changes in redox was not clearly seen. In the unplanted soil, redox was reduce to highly reduce, with the overall changes ranging from -70 $\mathrm{mV}$ at the surface to $-100 \mathrm{mV}$ at deep. The influence of biomass on the changes in redox was not clearly evident (Fig. 7).

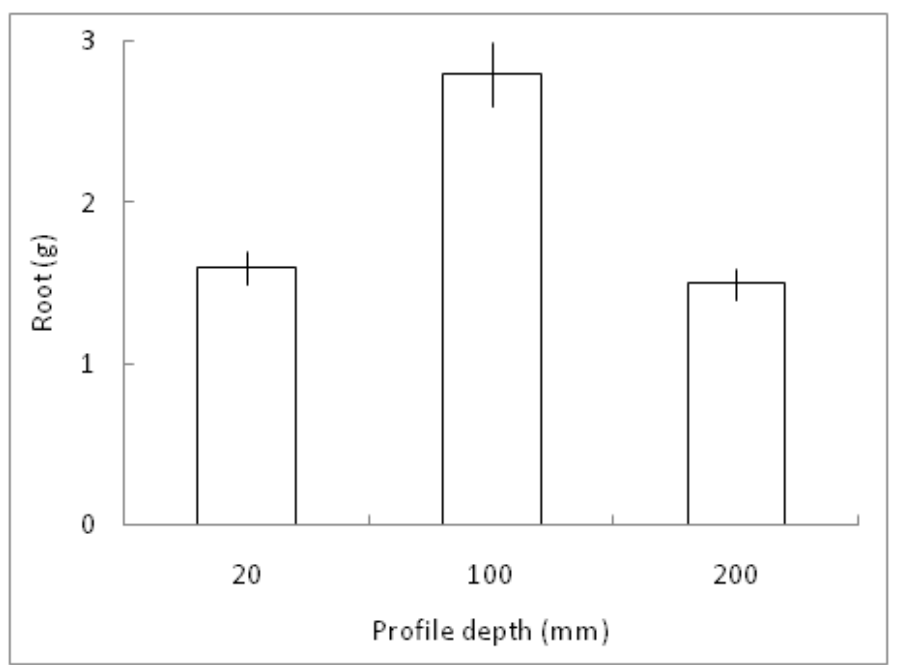

Figure 5. Distribution of root biomass without added organic matter amendment under flooded conditions after 6 months. [The values are mean \pm s.e. of three replicate measurements] 


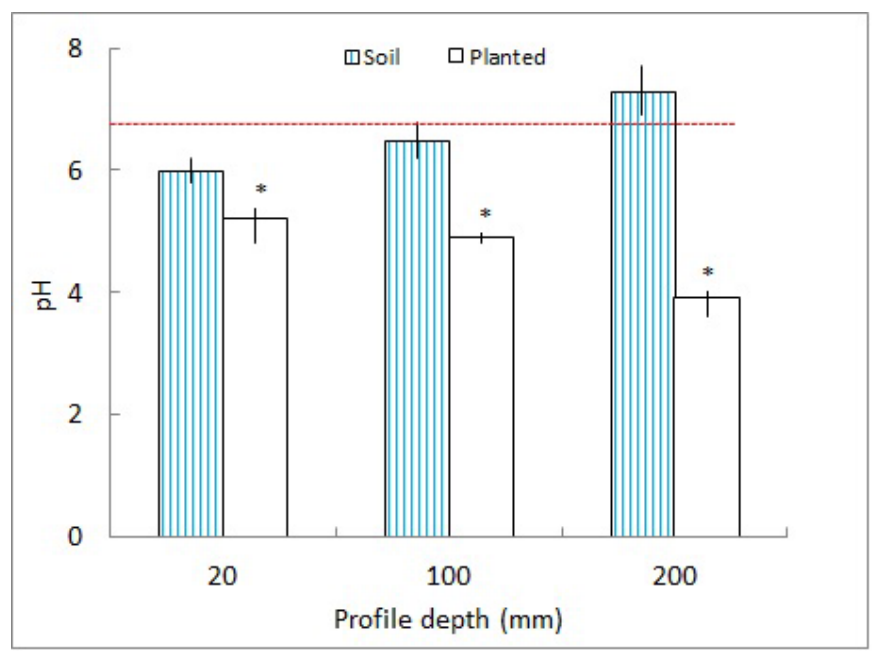

Figure 6. Effects of live roots on $\mathrm{pH}$ of soil without added organic matter under flooded soil conditions after 6 months. [The dotted line is the initial $\mathrm{pH}$. The values are mean \pm s.e. of three replicate measurements. An asterisk indicates significant difference $(\mathrm{p}<0.05)$ between treatment and control at same depth]

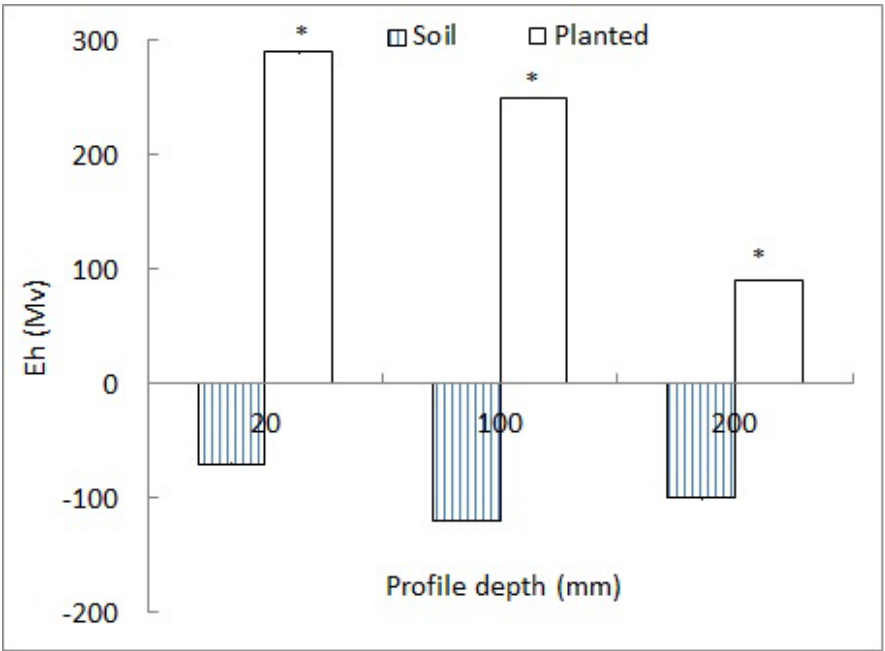

Figure 7. Effects of live roots on redox potential of soil without added organic matter under flooded soil conditions after 6 months. [The values are mean \pm s.e. of three replicate measurements. An asterisk indicates significant difference $(p<0.05)$ between treatment and control at same depth]

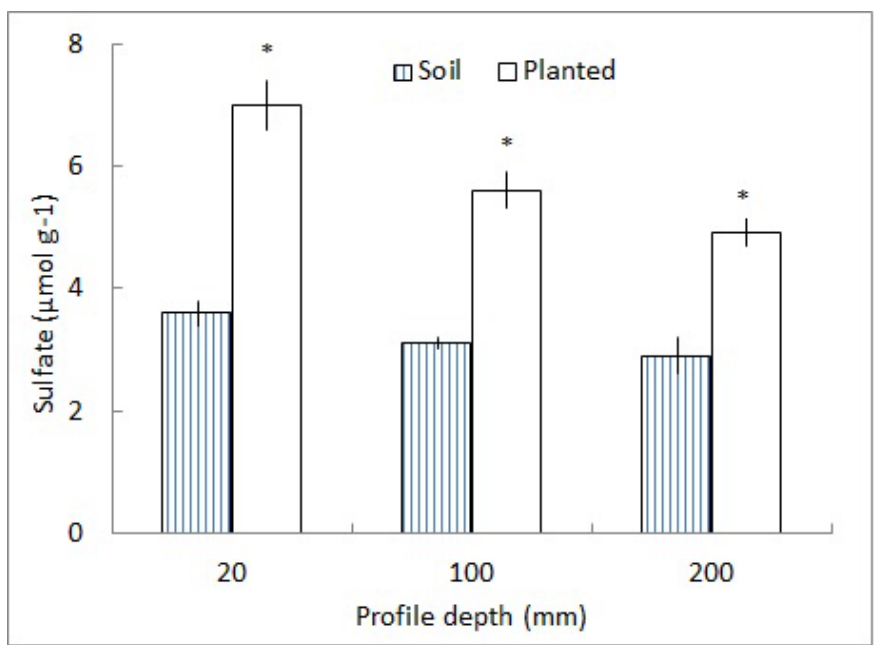

Figure 8. Effects of live roots on sulfate content of soil without added organic matter under flooded soil conditions after 6 months. The initial sulfate content range from $12-16 \mu \mathrm{mol} \mathrm{g} \mathrm{g}^{-1}$ soil. The values are mean \pm s.e. of three replicate measurements. An asterisk indicates significant difference $(\mathrm{p}<0.05)$ between treatment and control at same depth.

\section{Effects of live plants alone on sulfate content}

The sulfate content was high in the planted soils (Fig. 8), consistent with the results of experiment 1 (Fig. 4) but the concentration was smaller at deep. In the unplanted soil, sulfate content remained nearly the same www.tropicalplantresearch.com 
throughout the profiles and much lower compared to the initial sulfate content (Fig. 8). Generally, no clear relationship between the biomass and the changes was found, consistent with those of experiment 1 .

\section{DISCUSSION}

Acid sulfate soils with sulfuric $(\mathrm{pH}<4)$ and sulfidic $(\mathrm{pH}>4)$ materials are widely distributed globally and are commonly associated with lakes, rivers and wetlands (Fitzpatrick et al. 2009). When submerged, these soils pose no problem because sulfides are retained in the reduced state (Michael et al. 2015). The sulfidic soil formation processes is shown in Equation 1 (Michael 2013). However, when exposed by falling water levels, e.g. during a drought event, the sulfides are oxidised and leads to generation of sulfuric acid through the reaction shown in Equation 2 (Michael et al. 2012).

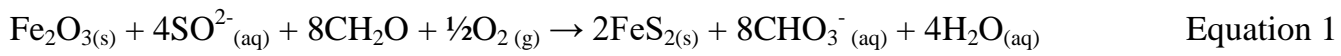

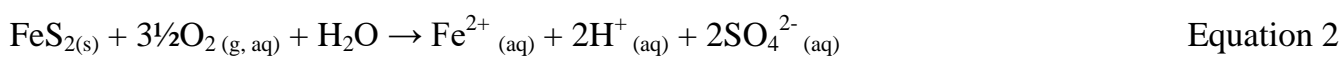

Associated with these water bodies where ASS are found are plants such as Phragmites australis that have become adapted to living in water of reduced oxygen as well as in acidic drained soils (Michael et al. 2017, Michael \& Reid 2018). Although the growth of the plants was not measured at the time of harvest, we have shown that this deep-rooted plant species has the potential to substantially alter the chemistry of ASS (Michael 2015, Michael \& Reid 2018). Despite the apparent differences in organic matter availability, this plant species was able to grow reasonably well but organic matter amendment resulted in bigger biomass (Fig. 1). In both of the experiments, more roots were produced in the middle of the soil profiles however it is very clear under none of the soil treatment conditions did the presence of live roots sustained sulfidic soil alkalinity. $\mathrm{pH}$ of all the planted soils decreased, shown in Figs. 2 \& 6.

The experiment without organic matter addition in particular showed $\mathrm{pH}$ to decline (Fig. 6) as much as when planted with organic matter (Fig. 2). Under the continuously flooded soil conditions, the influence of plants on $\mathrm{pH}$ was less pronounced in the soil with organic matter, which most likely reflects the dominant role of certain microbes depleting the oxygen transported via aerenchyma using the organic matter as a metabolic source. In the absence of added organic matter, the opposite happened. The mechanism underlying the adverse effects of live roots can be related to the processes occurring when dead plant material is either incorporated (Charoenchamratcheep et al. 1987) or distributed as surface mulch (Michael 2015b, Michael et al. 2017).

We reported that organic matter with high nitrogen content addition creates conducive microenvironments for aerobic microbes to proliferate and consume oxygen (Michael 2015, Michael et al. 2016) and cause the Eh to fall into the range in which sulfur-reducing bacteria can convert sulfate into sulfide, with an associated consumption of protons (Michael et al. 2015), stabilizing the sulfidic soil pH (Michael et al. 2014, Jayalath et al. 2016). This phenomenon explains the changes in soil chemistry of the unplanted soils with added organic matter, in addition to a moderate level of residual organic matter $(10.6 \%)$ already in the soil. The most obvious difference between the control soils and the planted soils was the large difference in Eh. The planted soils with organic matter resulted in higher Eh values within the $20 \mathrm{~mm}$ profile (Fig. 3), compared to planted soils without organic matter (Fig. 7). This was expected as the surface soil underwent drying sporadically as surface water fluctuated and deep soil remaining waterlogged all the time.

Plants adapted to growing in water have developed anatomical modifications capable of facilitating gaseous (oxygen and carbon dioxide) exchange between roots and shoots (Armstrong et al. 1996). This study demonstrated that Phragmites has the capacity to transport large amounts of oxygen into the rhizosphere and oxidise the soil, as evidenced by the high redox values, even under waterlogged conditions of limited oxygen, e.g. at the $200 \mathrm{~mm}$ profile (Fig. 7). The oxidation phenomenon was more pronounced in the soil without added organic matter. The probable explanation for this is that the oxygen delivered via the arenchyma to the rhizopshere oxidised the soil, even under the flooded soil conditions. Oxidation of the added organic matter by aerobic microbes further depleted the oxygen available in the soil. In the unplanted soils, redox was highly reduced in the absence of added organic matter (Fig. 7), as a result of the anoxia created by the flooding and the reduction reactions that ensured. In our previous studies, organic matter addition in sulfidic soil under various moisture regimes without live plants had similar changes in $\mathrm{pH}$, Eh and sulfate concentrations (Michael et al. 2015, 2016), confirming that organic matter addition ameliorates sulfidic soil chemistry even under falling soil moisture regimes. 
The plants were only six months old and the turnover of organic matter from them was small (Michael \& Reid 2018). In the soils with added organic matter co-existing with live plants, a high concentration of sulfate was measured at deep (Fig. 4), compared to the planted soil without added organic matter (Fig. 8). These differences probably resulted from the availability of nutrients and water that governed the types of microbial ecology established and their activities in inducing changes in soil chemistry (Bossio \& Scow 1995, Michael 2015b). Turnover of organic matter from mature plants can offset the acidifying effects of the live plants (Michael \& Reid 2018) however this study showed that the presence of plants in sulfidic soil under flooded soil conditions with organic matter leads to oxidation, resulting in low $\mathrm{pH}$ and high sulfate content. We previously reported the opposite, organic matter addition alone would sustain sulfidic soil alkalinity (Michael et al. 2015, 2016).

Under normal soil use and management conditions, organic matter addition as mulch or as turnover from leaf litter and organic compound secretion (even under falling moisture regimes) would enable soil microbes to act on these different substrates and consume acidity generated via Equation. 2, generating alkalinity (Michael et al. 2015, 2016, 2017). This will create micro-environments conducive to lower Eh, sulfate content and increase the $\mathrm{pH}$, important for management of sulfidic soil alkalinity $(\mathrm{pH}>4)$, during extreme climatic events. Presence of plants will accelerate the fall in soil moisture because of water use in photosynthetic reactions (Reid \& Butcher 2011), therefore, under such conditions, the plants need to be mowed to the ground and the shoot systems (above-ground biomass) removed (Michael et al. 2017). In the absence of the shoot systems, the remaining root systems (underground biomass) will use the culm to draw atmospheric oxygen into the soil and continue to oxidise the sulfidic materials (Michael \& Reid 2018). This management issue will most likely be addressed by reworking on the land, e.g. ploughing, and getting the exposed ends of the culms covered by soil to prevent oxygen penetration (Michael 2018a).

\section{CONCLUSION}

In contrast to the positive effects on sulfidic soil of organic mulches derived from dead plant material, turnover of organic matter as leaf litter or secretion of organic compounds from live plants, the growth of live plants with roots capable of transporting oxygen downwards via aerenchymatous tissue in sulfidic soil induces acidity rather than sustaining alkalinity. Organic matter addition gave rise to more biomass, resulting in more oxygen into the rhizosphere of the plants. Under a falling water regimes such as during a change in climatic conditions, an important management option would be to slash the plants and return them as mulch but would lead to deoxygenation under flooded soil conditions, becoming a problem for most benthic organisms. Culms would continue to transport oxygen into the soil if the slashed ends are not covered; therefore, reworking on the soil following slashing to prevent oxygen penetration is an important management option.

\section{ACKNOWLEDGEMENTS}

This study was funded by the Commonwealth of Australia through an ADS scholarship provided to Patrick S. Michael. Professors Robert Reid and Robert W. Fitzpatrick of University of Adelaide, School of Biological Sciences, were instrumental and their generous assistances are acknowledged. Thanks to the anonymous reviewers whose input improved the quality of the manuscript.

\section{REFERENCES}

Ahern CR, McElnea AE \& Sullivan LA (2004) Acid Sulfate Soils Laboratory Methods Guidelines. Queensland Department of Natural Resources, Mines and Energy, Indooroopilly, Queensland, Australia.

Armstrong J, Armstrong W, Beckett PM, Halder JE, Lythe S, Holt R \& Sinclair A (1996) Pathways of aeration and the mechanisms and beneficial effects of humidity-and Venturi-induced convections in Phragmites australis (Cav.) Trin. ex Steud. Aquatic Botany 54: 177-197.

Baldwin DS \& Fraser M (2009) Rehabilitation options for inland waterways impacted by sulfidic sediments - A synthesis. Journal of Environmental Management 91: 11-319.

Bossio DA \& Scow KM (1995) Impact of carbon and flooding on metabolic diversity of microbial communities in soil. Applied and Environmental Microbiology 61: 4043-4050.

Buschmann JM, Berg C, Stengel L, Winkel ML, Sampson TPT \& Viet PH (2008) Contamination of drinking water resources in the Mekong delta plains: arsenic and other trace metals pose serious health risks to population. Environmental International 34: 756-764.

Charoenchamratcheep C, Smith CJ, Satawathananont S \& Patrick WH (1987) Reduction and oxidation of acid sulfate soils of Thailand. Soil Science Society of America Journal 51: 630-634. 
Fiedler S, Vepraskas MJ \& Richardson JL (2007) Soil redox potential: importance, field measurements, and observations. In: Donald LS (ed) Advances in Agronomy. Academic Press, Salt Lake City, UT, USA, pp. 154.

Fitzpatrick R, Powell B \& Marvanek S (2008) Atlas of Australian acid sulfate soils. In: Fitzpatrick RW \& Shand P (eds) Inland Acid Sulfate Soil Systems Across Australia. CRC LEME, Perth, Australia, pp. 75-89.

Fitzpatrick RW, Grealish G, Shand P, Marvanek S, Thomas BP, Creeper N, Merry R \& Raven M (2009) Preliminary assessment of acid sulfate soil materials in Currency Creek, Finniss River, Tookayerta Creek and Black Swamp region, South Australia. Avalable from: CSIRO Land and Water Science Report 01/09, Adelaide, South Australia. Available from: http://www.clw.csiro.au/publications/science/2009/sr01-09.pdf. (accessed: 22 Jan. 2020).

Hoeft RG, Walsh LM \& Keeney DR (1973) Evaluation of various extractants for available soil sulfur. Soil Science Society of American Journal 37: 40-404.

Jayalath J, Mosely LM \& Fitzpatrick RW (2016) Addition of organic matter influences pH changes in reduced and oxidised acid sulfate soils. Geoderma 262: 125-132.

Marks M, Lapin B \& Randall J (1994) Phragmites australis (P. communis): threats, management and monitoring. Natural Areas Journal 14: 285-294.

Michael PS, Reid R \& Fitzpatrick RW (2012) Amelioration of slowly permeable hypersaline peaty-clayey sulfuric and sulfidic materials in acid sulfate soils by mixing with friable sandy loam soil. In: Burkitt LL \& Sparrow LA (eds) Proceedings of the 5th Joint Australian and New Zealand Soil Science Conference: Soil solutions for diverse landscapes. Hobart, Tasmania, Australia, pp. 146-149.

Michael PS (2013) Ecological impacts and management of acid sulphate soil: A review. Asian Journal of Water, Environment and Pollution 10: 13-24

Michael PS, Reid R \& Fitzpatrick RW (2014) Effects of organic matter amendment on acid sulfate soil chemistry. In: Clay C (ed) Proceedings of the $4^{\text {th }}$ National Acid Sulfate Soil Conference. Rendezvous Hotel, Perth, Australia, pp. 80-81.

Michael PS, Fitzpatrick RW \& Reid R (2015) The role of organic matter in ameliorating acid sulfate soils with sulfuric horizons. Geoderma 225: 42-49.

Michael PS (2015a) Effects of organic amendments and plants on the chemistry of acid sulfate soils under aerobic and anaerobic soil conditions, (Ph.D. Thesis). The University of Adelaide, South Australia, Australia.

Michael PS (2015b) Effects of alkaline sandy loam on sulfuric soil acidity and sulfidic soil oxidation. International Journal of Environment 4: 42-54.

Michael PS, Fitzpatrick RW \& Reid R (2016) The importance of carbon and nitrogen for amelioration of acid sulphate soils. Soil Use and Management 32: 97-105.

Michael PS, Fitzpatrick RW \& Reid R (2017) Effects of live wetland plant macrophytes on acidification, redox potential and sulphate content in acid sulphate soils. Soil Use and Management 33: 471-481.

Michael PS \& Reid R (2018) Impact of common reed and complex oranic matter on the chemistry of acid sulfate soils. Journal of Soil Science and Plant Nutrition 18: 542-555.

Michael PS (2018b) Comparative analysis of the ameliorative effects of soil carbon and nitrogen amendment on surface and subsurface soil pH, Eh and sulfate content of acid sulfate soils. Eurasian Soil Science 51: 11811190.

Michael PS (2018c) The role of surface soil carbon and nitrogen in regulating surface soil $\mathrm{pH}$ and redox potential of sulfidic soil of acid sulfate soils. Pertanika Journal of Tropical Agricultural Science 41: 16271642.

Michael PS (2018a) Effects of live plants and dead plant matter on the stability of pH, redox potential and sulfate content of sulfuric soil neutralized by addition of alkaline sandy loam. Malaysian Journal of Soil Science 22: 1-18.

Michael PS (2019) Phytoremediation of heavy metals by water hyacinth in sewage wastewater stabilization ponds under humid lowland tropical climatic conditions. International Journal of Environment 8: 30-42.

Pons LJ (1973) Outline of the genesis, characteristics, classifications and improvement of acid sulphate soils. In: Dost H (ed) International Symposium on Acid Sulphate Soils. Introductory Papers and Bibliography. International Institute for Land Reclaimation and Improvement, Wageningen, The Netherlands, pp. 3-27.

Rabenhorst MC, Hively WD \& James BR (2009) Measurements of soil redox potential. Soil Science Society of America Journal 73: 668-674. 
Reid RJ \& Butcher CS (2011) Positive and negative impacts of plants on acid production in exposed acid sulphate soils. Plant and Soil 349: 183-190.

Rynk R, Kamp M van de, Wilson GB, Singley ME, Richard TL, Kolega JJ, Gouin FR, Labberty L, Kay D, Murphy DW, Hoitink HAJ \& Brinton WF (1992) On-farm composting handbook. Natural Resource Agriculture and Engineering Service, Ithaca, New York, 204 p.

Schulte EE \& Hopkins BG (1996). Estimation of soil organic matter by weight loss-on-ignition. In: Magdoff FR, Tabatabai MA \& Hanlon EA (eds) Soil Organic Matter: Analysis and Interpretation. Soil Science Society of America, pp. 21-31.

Shamshuddin J, Muhrizal S, Fauziah I \& Husni, MHA (2004) Effects of adding organic materials to an acid sulfate soil on the growth of cocoa (Theobroma cacao L.) seedlings. Science of the Total Environment 323: $33-45$.

Simpson SL, Fitzpatrick RW, Shand P, Angel BM, Spadaro DA \& Mosley L (2010) Climate-driven mobilisation of acid and metals from acid sulfate soils. Marine and Freshwater Research 61: 129-138.

Soil Survey Staff (2014) Keys to Soil Taxonomy. United States Department of Agriculture Natural Resources Conservation Service, Washington, D.C.

Yan F, Schubert S \& Mengel K (1996) Soil pH changes during legume growth and application of plant materials. Biology and Fertility of Soils 23: 236-242. 